\title{
Effects of theophylline on inflammatory cells and cytokines in asthmatic subjects: a placebo-controlled parallel group study
}

\author{
J.P. Finnerty, C. Lee, S. Wilson, J. Madden, R. Djukanovic, S.T. Holgate
}

\begin{abstract}
Effects of theophylline on inflammatory cells and cytokines in asthmatic subjects: a placebo-controlled parallel group study. J.P. Finnerty, C. Lee, S. Wilson, J. Madden, R. Djukanovic, S.T. Holgate. C ERS Journals Ltd 1996.

ABSTRACT: The anti-inflammatory effects of oral theophylline on cells in bronchial biopsies of symptomatic atopic asthmatic subjects were investigated.

Following a 2 week run-in period, asthmatic subjects were randomly assigned to either placebo $(n=11)$ or theophylline $(n=15)$. Bronchial biopsies were taken at fibreoptic bronchoscopy at the beginning and end of a 6 week period, during which subjects took placebo or theophylline medication at a dose intended to produce therapeutic concentrations. Nine of the placebo subjects and 12 of the theophylline subjects completed the study.

Improvement in asthma control was seen in the theophylline-treated group. The mean (SD) theophylline blood level at the end of the study was $10.9(6.0) \mu \mathrm{g} \cdot \mathrm{mL}^{-1}$. A significant decrease in interleukin (IL)-4 expression from 1.38 to 1.04 cells $\cdot \mathrm{mm}^{-2}$ $(p<0.05)$ and a trend to a reduction in IL-5 from 1.29 to 0.48 cells $\cdot \mathrm{mm}^{-2}$ (NS) were seen in biopsies from the theophylline-treated group compared with placebo, although there was no change in mast cell numbers (judged by tryptase expression). A decrease in epithelial CD8+ cells from 2.60 to 0.53 cells $\cdot \mathrm{mm}^{-1}$ of surface $(\mathrm{p}<0.05)$ was noted.

This study shows an anti-inflammatory effect of theophylline in asthmatic bronchi, both in cell numbers and in the expression of IL-4, believed to be an important cytokine in the pathophysiology of asthmatic inflammation. We speculate that theophylline induces downregulation in vivo of cytokine production, accounting for the known inhibitory effect of theophylline on the late asthmatic reaction.

Eur Respir J., 1996, 9, 1672-1677.
\end{abstract}

Countess of Chester Hospital, Chester, UK.

Correspondence: J.P. Finnerty

Countess of Chester Hospital

Liverpool Road

Chester

CH2 1UL

UK

Keywords: Asthma

interleukin-4

interleukin-5

theophylline

Received: August 91995

Accepted after revision March 251996

This work was supported financially by Napp Laboratories, UK, who also provided the active and placebo medication used, and performed the HPLC theophylline assays described in the text.
Atopic asthma is characterized by an immune response to inhaled allergens in the airways [1]. Airways inflammation is observed in this condition, with increased numbers of eosinophils, mast cells and activated lymphocytes in bronchial biopsies [2]. Corticosteroids, the cornerstone of modern treatment of this condition, are believed to act by means of a variety of mechanisms resulting in inhibition of activation of inflammatory cells $[3,4]$. Theophylline, commonly used in the treatment of asthma, is a bronchodilator, but is widely believed to have additional actions beneficial in this disease, including anti-inflammatory actions [5]. In support of this concept, theophylline has been shown to inhibit the late asthmatic response (LAR) to inhaled allergen [6], and withdrawal of theophylline is associated with a rise both in CD4+ and CD8+ T-cells in bronchial biopsies [7].

We wished to assess in vivo the effect of theophylline on inflammatory cells in asthmatic subjects in a doubleblind, placebo-controlled, parallel-group study, based on analyses of paired bronchial biopsies. T-cell numbers were determined and T-cells characterized according to CD4 and CD8 status. The expression of a variety of activation markers and inflammatory cell products was also measured, including tryptase, eosinophil cationic protein, and interleukins (IL)-4 and -5. IL-4 is not only central to immunoglobulin $\mathrm{E}$ (IgE) production but also, through upregulation of the expression of vascular cell adhesion molecule-1 (VCAM-1) on endothelial cells is involved in the recruitment of eosinophils and T-cells [8]. IL-5 has profound effects on eosinophil maturation and activation [9], and IL-5 levels rise in bronchoalveolar fluid following allergen challenge in asthma, showing a correlation with eosinophil numbers [10]. Thus, these cytokines are believed to be important mediators of the airway inflammation observed in asthma.

\section{Study design}

This was a randomized double-blind, parallel-group study. For each subject, the study period was 8 weeks, comprising a 2 week run-in period and 6 weeks taking the trial medication, with five visits to the department.

At the first visit, subjects were randomized. Baseline lung function measurements in triplicate of forced expiratory volume in one second (FEV1) and peak expiratory flow (PEF) were made, and these were repeated at each subsequent visit. A methacholine bronchial challenge was performed. A diary card was issued, to record twice daily peak flow readings, asthma symptoms, and bronchodilator use throughout the study. 
At the second visit 2 weeks later, bronchoscopy was performed. On recovery, the subject was issued with either placebo tablets or controlled release theophylline tablets (Uniphyllin Continus tablets, Napp Laboratories Ltd).

At the third visit 1 week later, a theophylline assay was undertaken by an independent person in the department who then issued a blood theophylline result to the investigator: either the true result, or for those on placebo a value from a randomized set of dummy results. Drug dosage was altered accordingly for the remainder of the study.

At the fourth visit 1 week later, tolerance to the new dose was assessed, and if necessary dose adjustment made.

At the fifth visit 4 weeks later, and after 6 weeks of trial medication, a second bronchoscopy was performed, and bronchial biopsies taken as at the first bronchoscopy but from the opposite lung.

\section{Subjects}

Twenty six subjects, 8 females and 18 males, aged 18-55 yrs entered the study. All were required to have ongoing symptoms of asthma requiring at least daily use of an inhaled $\beta_{2}$-agonist, and subjects were permitted inhaled corticosteroids up to a maximum daily dose of $400 \mu \mathrm{g}$ of beclomethasone, provided the dose had remained constant for at least the previous month (table 1). Subjects were excluded if they smoked, or had a history of intolerance of theophylline, or if they had taken oral steroids or methylxanthines, or inhaled salmeterol, nedocromil or cromoglycate within 6 weeks of study entry. Inclusion criteria were: a baseline FEV1 on entry to the study of $>60 \%$ predicted [11]; demonstrable bronchial hyperreactivity to methacholine; and freedom from any respiratory infection within 6 weeks of study entry.

Fifteen subjects were randomly allocated to receive theophylline and 11 to receive placebo. All subjects were atopic, defined as $>3 \mathrm{~mm}$ skin wheel on skin prick testing with one or more of Dermatophagoides pteronyssinus, house dust, grass pollen, mould, dog hair, cat dander, and feathers (Bencard, Brentford, UK).

The study was approved by the Southampton Hospitals and University Joint Ethics Committee, and written informed consent was given by each subject.

\section{Methods}

\section{Bronchoscopy}

Each subject fasted for $6 \mathrm{~h}$ prior to bronchoscopy. Thirty minutes before bronchoscopy, atropine $0.6 \mathrm{mg}$ was given by intramuscular injection, and salbutamol 2.5 $\mathrm{mg}$ and ipratropium bromide $0.5 \mathrm{mg}$ were given via nebulizer. Intravenous access was obtained and intravenous midazolam given as necessary during the bronchoscopy. The nasal passages, larynx and major airways were anaesthetized using lignocaine spray. The bronchoscope was introduced through the nose, and bronchial biopsies were taken from the subcarina between the lower lobe and middle lobe/lingula. At least two macroscopically adequate biopsies were obtained whenever possible. Oxygen saturation was monitored throughout using an Ohmeda Biox pulse oximeter, and supplementary oxygen at 4 $\mathrm{L} \cdot \mathrm{min}^{-1}$ administered via the other nostril.

Table 1. - Subjects characteristics

\begin{tabular}{|c|c|c|c|c|c|}
\hline $\begin{array}{l}\text { Subject } \\
\text { No. }\end{array}$ & $\begin{array}{l}\text { Age } \\
\text { yrs }\end{array}$ & Sex & $\begin{array}{l}\text { FEV1 } \\
\% \text { pred }\end{array}$ & $\begin{array}{l}\mathrm{PC} 20 \\
\mathrm{mg} \cdot \mathrm{mL}^{-1}\end{array}$ & $\begin{array}{l}\text { Medication } \\
\text { daily }\end{array}$ \\
\hline \multicolumn{6}{|c|}{ Theophylline group } \\
\hline 3 & 41 & $\mathrm{~F}$ & 113 & 0.35 & $\mathrm{~S}, \mathrm{~B} 400 \mu \mathrm{g}$ \\
\hline 4 & 20 & $\mathrm{~F}$ & 95 & 0.29 & S, B $300 \mu g$ \\
\hline 7 & 20 & $\mathrm{~F}$ & 96 & 6.06 & $\mathrm{~S}$ \\
\hline 8 & 25 & M & 99 & 0.11 & $\mathrm{~S}$ \\
\hline 10 & 28 & M & 109 & 0.55 & $\mathrm{~S}$ \\
\hline 13 & 29 & M & 88 & 0.62 & $\mathrm{~S}$ \\
\hline 15 & 54 & M & 78 & 0.30 & $\mathrm{~S}, \mathrm{~B} 200 \mu \mathrm{g}$ \\
\hline 18 & 27 & M & 99 & 0.88 & $\mathrm{~F}, \mathrm{~B} 400 \mu \mathrm{g}$ \\
\hline 20 & 20 & M & 83 & 4.45 & $\mathrm{~S}, \mathrm{~B} 100 \mu \mathrm{g}$ \\
\hline 22 & 19 & M & 94 & 1.66 & $\mathrm{~S}$ \\
\hline 24 & 56 & M & 82 & 0.25 & $\mathrm{~S}$ \\
\hline 25 & 32 & $\mathrm{~F}$ & 106 & 0.13 & $\mathrm{~S}$ \\
\hline \multicolumn{6}{|c|}{ Placebo group } \\
\hline 2 & 31 & $\mathrm{~F}$ & 108 & 2.10 & $\mathrm{~S}$ \\
\hline 6 & 33 & M & 97 & 1.32 & $\mathrm{~S}$ \\
\hline 11 & 44 & M & 80 & 0.25 & $\mathrm{~S}$ \\
\hline 12 & 23 & M & 104 & 1.00 & S, B $200 \mu q$ \\
\hline 16 & 53 & M & 66 & 0.07 & $\mathrm{~S}$ \\
\hline 17 & 25 & M & 77 & 1.80 & $\mathrm{~S}$ \\
\hline 19 & 21 & $\mathrm{~F}$ & 103 & 0.06 & $\mathrm{~S}, \mathrm{~B} 400 \mu \mathrm{g}$ \\
\hline 21 & 29 & M & 96 & 8.16 & $\mathrm{~S}$ \\
\hline 26 & 45 & $\mathrm{~F}$ & 105 & 7.68 & $\mathrm{~T}$ \\
\hline
\end{tabular}

M: male; F: female; FEV1: forced expiratory volume in one second; $\mathrm{PC} 20$ : provocative concentration of methacholine causing a $20 \%$ fall in FEV1. B: beclomethasone MDI: S: Salbutamol MDI p.r.n.; T: terbutaline MDI p.r.n.; F: fenoterol MDI p.r.n.; MDI: metered-dose inhaler. 


\section{Bronchial biopsies}

Bronchial biopsies were placed immediately into icecold acetone containing protease inhibitors $(2 \mathrm{mM}$ phenyl methyl sulphonyl fluoride, $20 \mathrm{mM}$ iodoacetamide) and fixed overnight at $-20^{\circ} \mathrm{C}$. Biopsies were then processed into glycolmethacrylate (GMA) resin according to the method of BRITTEN et al. [12].

Sections of $2 \mu \mathrm{m}$ thickness were cut and stained immunohistochemically using the streptavidin biotin detection system. The mouse monoclonal antibodies used were: AA1, an anti-tryptase antibody to demonstrate mast cells (Dako); EG2 to eosinophil cationic protein to detect eosinophils (Pharmacia); anti-CD3 (Dako), CD4 (Becton Dickson), and CD8 (Dako) for the demonstration of Tlymphocytes and their subsets; 4D9, an anti-IL-4 antibody (Ciba-Geigy, Switzerland) which detects IL-4 in its granular stored form, and Mab7, an anti-IL-5 antibody (provided by P. Hissey, Glaxo, UK). The number of positive nucleated cells were counted in the submucosa, the area of the section measured, and the results expressed as the number of positive cells $\cdot \mathrm{mm}^{-2}$ of submucosa. The number of positive nucleated cells were also counted in the epithelium, and the results were expressed as number of positive cells $\cdot \mathrm{mm}^{-1}$ length of epithelium examined.

\section{Diary cards}

A daily record of morning and evening PEF, frequency of use of an inhaled $\beta_{2}$-agonist and asthma symptoms was made. The score for daytime symptoms was on a scale from 0 (no symptoms) to 3 (asthma bad, unable to carry out normal daily activities). Nocturnal symptoms were scored on a scale from 0 (slept through the night) to 3 (bad night, kept awake most of the time by asthma).

\section{Theophylline assays}

The theophylline levels during the course of the study were estimated from fresh venous blood samples, using a commercially available test based on enzyme immunochromatography (Acculevel theophylline test, Syntex Medical Diagnostics). This gave a result within $40 \mathrm{~min}$ of blood sampling. Based on this result, the investigator adjusted the dose of slow-release theophylline administered, using an in-house computer program and aiming at a steady-state concentration (Css) of $12.5 \mu \mathrm{g} \cdot \mathrm{mL}^{-1}$. Plasma samples taken at the end of the study prior to the second bronchoscopy were estimated by reversed phase high performance liquid chromatography (RP-HPLC) by Napp Research Laboratories, Cambridge, UK.

\section{Data analysis}

Clinical efficacy was assessed by comparing changes in values of FEV1 and PEF between Visit 2 (pretreatment) and Visit 5 (post-treatment), and similarly by comparing changes in diurnal variation (DV) in PEF from diary cards between the means of the 14 days prior to
Visit 2 and the 14 days prior to Visit 5. Diurnal variation was calculated as follows:

$$
\mathrm{DV}=\frac{\text { PEF (following morning) - PEF (previous evening) }}{\text { PEF (previous evening) }} \times 100
$$

The two treatment groups were compared firstly with respect to: 1) baseline values of these respiratory parameters, to assess whether the treatment groups were different at the start of the treatment period; and 2) differences in values between Visits 2 and 5 were compared between the two groups to assess treatment effects. The same applies to analyses of the various parameters of cellular activity in bronchial biopsy specimens. The t-test was used to analyse all parametric variables, and in some cases (stated in the text) the Wilcoxon rank sum test or Mann-Whitney U-test was used to analyse nonparametric variables. Each t-test was performed independently and the significance levels reported are those for each individual test (two-tailed). To reduce the risk of a type 1 error $(\alpha)$, the comparisons were grouped as follows: three comparisons were made of epithelial cell counts; three comparisons were made of submucosal cell counts; and five comparisons were made of markers of cell activation. Since the a priori hypothesis was that inflammatory cells and their markers would be diminished by theophylline, the p-values for each comparison were recalculated to give a $5 \%$ risk one-tailed of a type 1 error for each group.

\section{Results}

A total of five subjects withdrew from the study, three from the theophylline group and two from the placebo group, so that 12 subjects from the theophylline group and nine from the placebo group completed the study. Of those withdrawn from the theophylline group, one was unable to tolerate the initial bronchoscopy, one developed intolerable dyspepsia attributed to theophylline, and one suffered an exacerbation of asthma associated with an upper respiratory tract infection. Of those withdrawn from the placebo group, one subject had inadequate time to attend for study visits, and one failed to demonstrate bronchial hyperreactivity on study entry.

\section{Clinical efficacy, lung function and theophylline levels}

For the theophylline group, the mean baseline FEV1 $( \pm \mathrm{SD})$ was $3.69( \pm 1.04) \mathrm{L}, 95( \pm 19) \%$ of predicted; while for the placebo group, the mean baseline FEV1 was 3.50 $( \pm 0.68)$ L, $95( \pm 17) \%$ of predicted (NS). Similarly, there were no significant baseline differences between the two treatment groups with respect to baseline PEF or diurnal variation in PEF from diary records.

In the theophylline group, the PEF recorded at clinic visits significantly $(\mathrm{p}<0.05)$ increased from a mean $(\mathrm{SD})$ of $530( \pm 101)$ to $559( \pm 118) \mathrm{L} \cdot \mathrm{min}^{-1}$; while in the placebo group the mean PEF was $532( \pm 80) \mathrm{L} \cdot \mathrm{min}^{-1}$ at the beginning of the treatment period and $523( \pm 76) \mathrm{L} \cdot \mathrm{min}^{-1}$ at the end of the treatment period (NS). In the theophylline 
Table 2. - Frequency of use of $\beta_{2}$-agonist inhaler

\begin{tabular}{lll}
\hline Treatment & Time $^{\dagger}$ & $\begin{array}{c}\text { Daily use } \\
\text { doses }^{\#}\end{array}$ \\
\hline $\begin{array}{l}\text { Daytime use } \\
\text { Theophylline }\end{array}$ & $\begin{array}{l}\text { Run-in } \\
\text { End }\end{array}$ & $1.42(1.55)$ \\
Placebo & Run-in & $0.92(1.32)$ \\
& End & $1.18(0.56)$ \\
Nocturnal use & Run-in & $0.34(0.67)$ \\
Theophylline & End & $0.36(0.45)$ \\
& Run-in & $0.28(0.41)$ \\
Placebo & End & $0.37(0.45)$ \\
&
\end{tabular}

\# : mean value, and SD in parenthesis; $\uparrow:$ this refers to the timeperiod of measurement, where Run-in refers to averaged use in 14 days of run-in and End refers to the final 14 days of the treatment period.

treated group, mean $( \pm \mathrm{SD})$ daytime frequency of $\beta_{2}$-agonist inhaler use from diary records was $1.42( \pm 1.55)$ times daily prior to the treatment period and $0.92( \pm 1.32)$ times daily at the end of the treatment period (NS). Inhaled $\beta_{2}$-agonist use did not differ from the frequency of use in the placebo-treated group (table 2). Daytime asthma symptom scores from diary records did not differ across the theophylline treatment period, nor between placebo and theophylline treatment periods. There was a significant difference between the changes in nocturnal symptoms across the treatment period when the theophylline treatment period was compared to the placebo treatment period $(\mathrm{p}<0.05)$ with a small increase in nocturnal symptoms in the placebo treated group and decrease in symptoms in the theophylline treated group (table 3).

During the second bronchoscopy at the end of the treatment period, the mean (SD) theophylline blood level was $10.9(6.0) \mu \mathrm{g} \cdot \mathrm{mL}^{-1}$ in the theophylline treatment group, and undetectable in all subjects in the placebo group. Based on these measurements, the mean Css (range) was estimated at $11.0(4.9-18.1) \mu \mathrm{g} \cdot \mathrm{mL}^{-1}$.

\section{Cell counts in bronchial biopsies}

Bronchial epithelium. For several of the cell counts reported for the epithelium, cell numbers were so low that

Table 3. - Asthma symptom scores

\begin{tabular}{lll}
\hline Treatment & Time† & $\begin{array}{c}\text { Symptom } \\
\text { score }^{\#}\end{array}$ \\
\hline $\begin{array}{l}\text { Daytime } \\
\text { Theophylline }\end{array}$ & $\begin{array}{l}\text { Run-in } \\
\text { End }\end{array}$ & $0.54(0.38)$ \\
Placebo & Run-in & $0.26(0.37)$ \\
Night-time & End & $0.68(0.29)$ \\
Theophylline & Run-in & $0.60(0.55)$ \\
Placebo & End & $0.23(0.28)$ \\
& Run-in & $0.18(0.30)$ \\
& End & $0.12(0.18)$ \\
\hline
\end{tabular}

\# : mean value, and SD in parenthesis; $\dagger$ : this refers to the timeperiod of measurement, where Run-in refers to averaged scores in 14 days of Run-in and End refers to the final 14 days of the treatment period.
Table 4. - Cell counts positive for specific cell markers in epithelium of bronchial biopsies from placebo and theophylline-treated subject

\begin{tabular}{lccc}
\hline & \multicolumn{3}{c}{ Cell counts cells $\mathrm{mm}^{-1}$} \\
Groups & $\mathrm{CD} 3+$ & $\mathrm{CD} 4+$ & $\mathrm{CD} 8+^{*}$ \\
\hline Theophylline $(\mathrm{n}=7)$ & & & \\
1st bronchoscopy & $2.82(1.05)$ & $0.89(0.60)$ & $2.60(1.05)$ \\
2nd bronchoscopy & $3.14(1.77)$ & $0.13(0.09)$ & $0.53(0.37)$ \\
Placebo (n=6) & & & \\
1st bronchoscopy & $2.47(1.61)$ & $0.53(0.22)$ & $0.57(0.27)$ \\
2nd bronchoscopy & $3.16(1.28)$ & $0.51(0.51)$ & $1.61(0.54)$ \\
\hline
\end{tabular}

Values are presented as mean, and SEM in parenthesis. $*: \mathrm{p}<0.01$ (comparison between groups).

meaningful analysis was not possible. Results were obtained for CD3+, CD4+ and CD8+ cells (table 4). Numbers of $\mathrm{CD} 3+$ cells remained virtually unchanged over the course of the study in both groups, being $3.16 \pm 1.28$ cells $\cdot \mathrm{mm}^{-1}$ at the end of the placebo period and 3.14 \pm 1.76 cells $\cdot \mathrm{mm}^{-1}$ at the end of the theophylline period. Similarly, no significant change in CD4+ cells could be shown between the groups, although the cell count in the theophylline-treated group did fall from a mean of 0.89 to 0.13 cells $\cdot \mathrm{mm}^{-1}$ over the treatment period (NS).

However, for CD8+ cells there was a fivefold fall in the theophylline-treated group from $2.60 \pm 1.05$ to $0.53 \pm 0.37$ cells $\cdot \mathrm{mm}^{-1}(\mathrm{p}<0.05$, Wilcoxon); whereas, in the placebotreated group the cell counts increased from $0.57 \pm 0.24$ cells $\cdot \mathrm{mm}^{-1}$ at the beginning to $1.61 \pm 0.54$ cells $\cdot \mathrm{mm}^{-1}$ at the end of the treatment period. The differences in changes of CD8+ cell counts over the study period between the two groups were significant $(\mathrm{p}<0.01$, two-tailed $)(\mathrm{p}=0.012$, one-tailed, $\alpha<0.05$ one-tailed for three comparisons) (fig. 1).

Bronchial submucosa. The numbers of CD3+ cells in the submucosa of bronchial biopsies was comparable between the placebo- and theophylline-treated groups at the first bronchoscopy and showed no significant change at the second bronchoscopy. Similarly, no significant changes in the numbers of CD4+ and CD8+ cells were observed in either group (table 5).

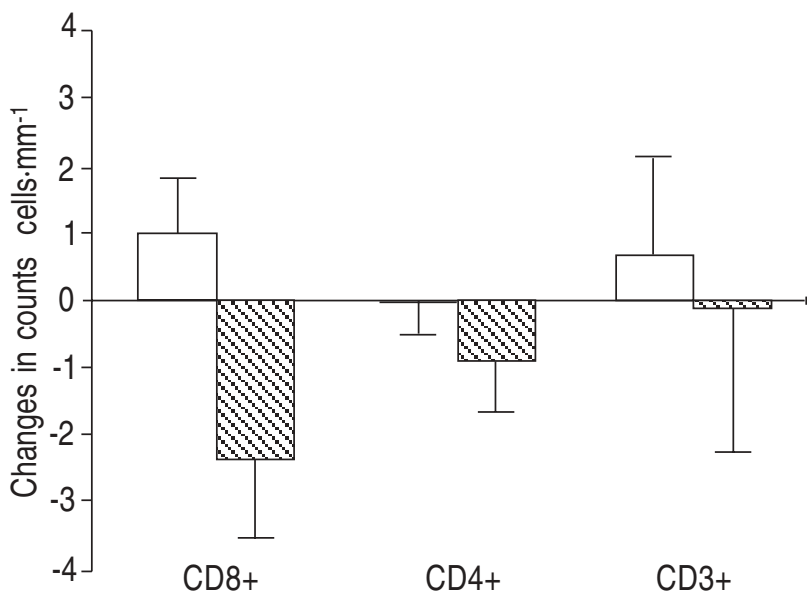

Fig. 1. - Changes in epithelial cell counts (cells $\mathrm{mm}^{-1}$ bronchial mucosa) for cells stained for CD3+, CD4+ and CD8+ over the study period both for placebo ( $\square$ ) and theophylline $(\square)$ p $<0.05$ for comparison between theophylline and placebo changes for $\mathrm{CD} 8+$ cells. 
Table 5. - Cell counts positive for specific cell markers in submucosa of bronchial biopsies from placebo and theophylline-treated subjects

\begin{tabular}{lcccccccc}
\hline \multicolumn{7}{c}{ Cell counts cells·mm ${ }^{-2}$} \\
Groups & CD3+ & CD4+ & CD8+ & Tryptase & EG2 & IL-4* & IL-5 & ECP \\
\hline Theophylline (n=8) & & & & & & & \\
1st bronchoscopy & $37.8(9.3)$ & $17.7(3.3)$ & $14.8(5.9)$ & $5.65(1.06)$ & $4.99(0.84)$ & $1.38(0.39)$ & $1.29(0.60)$ & $3.36(2.11)$ \\
2nd bronchoscopy & $42.1(12.9)$ & $14.7(5.0)$ & $11.7(3.8)$ & $4.23(1.21)$ & $2.89(0.81)$ & $1.04(0.29)$ & $0.48(0.39)$ & $2.15(0.91)$ \\
Placebo (n=7) & & & & & & & & \\
1st bronchoscopy & $34.6(7.1)$ & $21.6(5.1)$ & $11.4(2.3)$ & $8.40(1.79)$ & $4.90(1.81)$ & $0.68(0.19)$ & $0.05(0.05)$ & $3.49(1.27)$ \\
2nd bronchoscopy & $24.7(3.9)$ & $9.3(2.1)$ & $8.5(2.4)$ & $7.18(1.49)$ & $2.54(0.63)$ & $2.85(0.88)$ & $0.77(0.25)$ & $3.87(1.15)$ \\
\hline
\end{tabular}

Values are presented as mean, and SEM in parenthesis. IL: interleukin; ECP: eosinophil cationic protein. *: p<0.05 (comparison between changes in each groups).

In those who received placebo, numbers of cells positive for IL-4 and IL-5, initially low, increased at the second bronchoscopy, whereas for the theophylline-treated asthmatics, the reverse was seen, with a reduction in the numbers of IL-4 and IL-5-staining cells observed at the second bronchoscopy. This reached statistical significance for IL-4 ( $\mathrm{p}=0.014$, two-tailed), even correcting for multiple comparisons $(p=0.007$, one-tailed, $\alpha<0.05$ for five comparisons) (table 5). The scatter of the data for IL-5 indicated that a nonparametric comparison was appropriate, giving a significant result if considered in isolation ( $\mathrm{p}=0.04$, Mann-Whitney U-test), although this did not reach statistical significance if correction was made for multiple comparisons ( $\mathrm{p}=0.02$, one-tailed, $\alpha>0.05$ for five comparisons).

\section{Discussion}

This study has shown an inhibitory effect of oral theophylline on the expression of IL-4 (and a trend to reduction in IL-5 expression) on cells in the bronchial submucosa of asthmatics, and a reduction in epithelial numbers of CD8+ cells. These findings add further support to the concept of an anti-inflammatory role for theophylline.

Several studies have indicated a protective effect of theophylline against the late asthmatic response to allergen inhalation in vivo. CRESCIOLI et al. [13] showed significant inhibition of allergen-induced increases in bronchial responsiveness to methacholine following 1 week of oral theophylline therapy. PAuwels et al. [6] showed that intravenous theophylline had a modest inhibitory effect on bronchoconstriction in the early asthmatic response to allergen, and a marked inhibitory effect on bronchoconstriction during the LAR, and this finding has been replicated in other studies $[14,15]$. These in vivo data indicate a specific effect on the LAR which is not explicable simply in terms of the smooth muscle bronchodilator effect of theophylline.

A number of recent studies have focused on the potential immunomodulatory role for theophylline in asthma. WARD et al. [15] showed that chronic theophylline therapy attenuated increases in T-cell numbers in peripheral blood associated with the LAR. KIDNEY et al. [7] showed that on withdrawal of theophylline therapy of six months duration or longer, there was an increase in numbers of CD8+ and CD4+ cells in bronchial biopsies, suggesting that theophylline inhibited the recruitment of these cells into the airways. An inhibitory effect of theophylline on lymphocyte numbers in bronchoalveolar lavage in asthmatics has also been reported, with significant reductions in total T-cells and the CD8+ subset (Z. Jaffar, personal communication). There is in vitro evidence of the ability of theophylline to inhibit T-cell proliferation [16], possibly by inhibiting IL-2 generation [17].

Of interest in the current study is the observed reduction in levels of IL- 4 and IL-5 staining cells in the epithelium of the theophylline-treated group. The cellular provenance of these cytokines was not identified, although IL-5, the main factor promoting terminal differentiation of eosinophil precursors and enhancing the effector capacity of mature eosinophils, is known to be produced by activated T-cells [18], and messenger ribonucleic acid (mRNA) for IL-5 has been identified in eosinophils in asthma. We have recently shown that in allergic disease the mast cell is an important source of preformed IL-4, and may well be of major importance in maintaining chronic mucosal inflammation [19]. These cytokines together with tumour necrosis factor- $\alpha$ (TNF- $\alpha$ ) and IL-6 are accessible for immediate release upon IgE-dependent cell activation, and may well be responsible for eosinophil recruitment and subsequent disordered airway function in the LAR to allergen.

The fall in CD8+ cells in the epithelium of theophyllinetreated patients in our study is consistent with previous work indicating a rise in CD8+ cells in bronchial biopsies on withdrawal of chronic theophylline therapy [20]. Recent work indicates that CD8+ T-cells, conventionally regarded as suppressor cells, can differentiate to produce cytokines of the type 2 T-helper (Th2) type in the same manner as CD4+ cells, and thus may actively contribute to allergic processes [21, 21].

The apparent reduction in the numbers of IL-4 and IL5 staining cells was not accompanied by a reduction in the number of mast cells and eosinophils, identified by the cell specific markers, tryptase and eosinophil cationic protein, respectively. Our study suggests that theophylline is downregulating the expression of IL-4 and IL-5, possibly at the level of cytokine transcription. The reduced availability of preformed IL-4 and IL-5 may, in part, explain the inhibitory effects of theophylline on stimuli which trigger mast cells to release both classical mediators, such as histamine and leukotrienes, and cytokines. An inhibitory effect of theophylline both on IL-4 and IL-5 might well be expected to inhibit the acute 
recruitment of eosinophils to the airways during the LAR, which involves upregulation of specific vascular adhesion molecules. This is consistent with recent work showing that chronic theophylline therapy reduces circulating levels of eosinophil cationic protein [23] and inhibits allergen-induced eosinophil activation and recruitment to asthmatic airways [20].

In conclusion, the current study shows that 6 weeks of oral theophylline therapy induces a reduction in the expression of the cytokine interleukin- 4 and a trend to reduction in expression of interleukin-5 on submucosal airways cells and a reduction in CD8+ T-cells in the airway epithelium. This provides a biologically plausible explanation for the inhibitory effects of theophylline on the clinical and cellular events of the late asthmatic response noted in previous studies, and may in part explain the long-term beneficial effects of theophylline in asthma.

\section{References}

1. Robertson DG, Kerigan AT, Hargreave FE, Chalmers R, Dolovich J. Late asthmatic responses induced by ragweed pollen allergen. J Allergy Clin Immunol 1974; 54: 244-254.

2. Djukanovic R, Roche WR, Wilson JW, et al. Mucosal inflammation in asthma. Am Rev Respir Dis 1990; 142: 434-457.

3. Hirata F, Schiffman E, Venkatasubramanian K, Salomon $\mathrm{D}$, Axelrod J. A phospholipase $\mathrm{A}_{2}$ inhibitory protein in rabbit neutrophils induced by glucocorticoids. Proc Natl Acad Sci USA 1980; 77: 2533-2536.

4. Blackwell GJ, Carnuccio R, Di Rosa M, Flower RJ, Parente L, Persico P. Macrocortin: a polypeptide causing the antiphospholipase effects of glucocorticoids. Nature 1980; 287: 147-149.

5. Barnes PJ, Pauwels RA. Theophylline in the management of asthma: time for reappraisal? Eur Respir J 1994; 7: 579-591.

6. Pauwels R, Van Reuterghem D, Ven der Straeten M, Johannssen N, Persson CGA. The effect of theophylline and enprofylline on allergen-induced bronchoconstriction. J Allergy Clin Immunol 1985; 76: 583-590.

7. Kidney JC, Dominguez M, Taylor P, et al. Withdrawing chronic theophylline treatment increases airway lymphocytes in asthma. Thorax 1994; 49: 396P.

8. Schleimer RP, Sterbinsky SA, Kaiser J, et al. IL-4 induces adherence of human eosinophils and basophils but not neutrophils to endothelium: association with expression of VCAM-1. J Immunol 1992; 148: 1086-1092.

9. Lopez AF, Sanderson CJ, Gamble JR, Campbell HD,
Young IG, Vadas MA. Recombinant human interleukin-5 is a selective activator of human eosinophil function. J Exp Med 1988; 167: 219-224.

10. Virchow J-C, Walker C, Hafner D, et al. T-cells and cytokines in bronchoalveolar lavage fluid after segmental allergen provocation in atopic asthma. Am J Respir Crit Care Med 1995; 151: 960-968.

11. Quanjer PhH, Dalhuijsen A, van Zomeren BC. Summary equations of reference values. Bull Eur Physiopathol Respir 1983; 19(Suppl. 5): 45-51.

12. Britten KM, Howarth PH, Roche WR. Immunohistochemistry of resin sections, a comparison of resin embedding techniques for small mucosal samples. Biotech Histochem 1993; 67: 271-280.

13. Crescioli S, Spinnazzi A, Plebani M, et al. Theophylline inhibits early and late asthmatic reactions induced by allergens in asthmatic subjects. Ann Allergy 1991; 66: 245-251.

14. Hendeles L. Theophylline attenuation of allergeninduced airway hyperreactivity and late response. $J$ Allergy Clin Immunol 1991; 87: 167 (Abstract).

15. Ward AJM, McKenniff M, Evans JM, Page CP, Costello JF. Theophylline: an immunomodulatory role in asthma. Am Rev Respir Dis 1993; 147: 518-523.

16. Limatibul S, Shore A, Dorsch HM, Gelfand E. Theophylline modulation of E-rosette formation: an indicator of T-cell maturation. Clin Exp Immunol 1978; 33: 503-513.

17. Mary D, Aussel C, Ferrua B, Fehlmann M. Regulation of interleukin-2 synthesis by cAMP in human T-cells. $J$ Immunol 1987; 139: 1179-1184.

18. Hamid Q, Azzawi M, Ying S, et al. Interleukin-5 mRNA in mucosal bronchial biopsies from asthmatic subjects. Int Arch Allergy Appl Immunol 1991; 94: 169-170.

19. Bradding P, Feather IH, Wilson S, et al. Immunolocalization of cytokines in the nasal mucosa of normal and perennial rhinitic subjects: the mast cell as a source of IL-4, IL-5 and IL-6 in human allergic mucosal inflammation. J Immunol 1993; 151: 3853-3865.

20. Sullivan P, Bekir S, Jaffar Z, Page C, Jeffrey P, Costello J. Anti-inflammatory effects of low-dose oral theophylline in atopic asthma. Lancet 1994; 343: 1006-1008.

21. Maggi E, Giudizi MG, Biagiotti R, et al. Th2-like CD8+ T-cells showing B-cell helper function and reduced cytolytic activity in human immunodeficiency virus type 1 infection. $J$ Exp Med 1994; 180(2): 489-495.

22. Le Gros G, Erard F. Noncytotoxic, IL-4, IL-5, IL-10 producing CD8+ T-cells: their activation and effector functions. Curr Opin Immunol 1994; 6(3): 453-457.

23. Venge P, Dahl R, Karlstrom R, Pedersen B, Peterson C. Eosinophil and neutrophil activity in asthma in a one year double-blind trial with theophylline and two doses of inhaled budesonide. J Allergy Clin Immunol 1992; 89: A181. 